\title{
KEHARMONISAN RUMAH TANGGA \\ PEMAIN PERSATUAN SEPAK BOLA INDONESIA BALIKPAPAN \\ (PERSIBA)
}

\author{
Ridwan Ponamon \\ Sekolah Tinggi Ilmu Syari’ah (STIS) Hidayatullah Balikpapan \\ El.ridwan93@gmail.com \\ Muh. Zaim Azhar \\ Sekolah Tinggi Ilmu Syari’ah (STIS) Hidayatullah Balikpapan \\ zaimazhar86@yahoo.com
}

\begin{abstract}
Abstrak
Pernikahan adalah merupakan sesuatu yang sakral yang bertujuan membangun keluarga yang sakinah mawaddah warahmah dengan menyatukan dua insan yang berbeda, suami memiliki tanggung jawab mendidik, mengayomi, dan menafkahi istri dan anaknya. keberadaan suami ditengah-tengah keluarganya sangat dibutuhkan agar dapat memberikan keteladanan dalam membimbing anak dan istrinya agar terwujudnya keharmonisan dalam keluarga. Karena itu kondisi keluarga yang sering ditinggal oleh kepala keluarganya demi tuntutan profesi atau untuk mencari nafkah, perlu dikaji dan dianalisis. Tulisan ini akan menganalisis beberapa kasus keluarga pesepak bola dalam kaitannya dengan Keharmonisan rumah tangga mereka. Kesimpulan dari hasil penelitian ini bahwa gambaran keharmonisan rumah tangga pemain sepak bola Indonesia Balikpapan (PERSIBA) adalah baik, karena merupakan kewajiban suami sebagai kepala keluarga untuk mendidik dan menafkahi keluarganya sekalipun harus berjauhan.
\end{abstract}

\section{Keywords: Pernikahan, Keharmonisan, pesepak bola.}

\section{A. Pendahuluan}

Dalam penciptaan makhluk, Allah senantiasa menciptakannya secara berpasangan. Manusia diciptakan Allah pun berpasangan antara laki-laki dan perempuan agar dapat mengembangkan keturunan, seperti disyaratkan Allah dalam QS. Al-Dzariyat[51]: 49

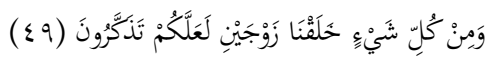

Artinya : Dan dari segala sesuatu kami ciptakan berpasang-pasangan supaya kamu mengingat kebesaran Allah. (QS Al-Dzariyat: 9)

Untuk dapat mengembangkan keturunan dan melestarikan kehidupan, Allah memberi insting seksual kepada makhluk-Nya, termasuk manusia. Akan tetapi perilaku seksual haram dilakukan, kecuali dengan ikatan pernikahan (Mitsaqon Ghalidzah). Allah mensyariatkan pernikahan karena dengan menikah terjadi akad 
yang menghalalkan ke dua bela pihak (suami dan istri) menikmati pihak satunya. ${ }^{1}$

Hikmah pernikahan yaitu rasa tanggung jawab untuk menafkahi keluarga dan mengayomi anak-anak dapat menumbuhkan semangat untuk bekerja dan menampakkan kreatifitasnya. Semua itu dilakukan sebagai rasa tanggung jawab untuk memenuhi kebutuhan rumah tangganya. Dengan demikian, dunia usaha akan semakin berkembang dan mendorong investasi yang dapat memicu kesejahteraan dengan banyaknya produksi yang dapat digarap, yang semua itu telah disediakan oleh Allah SWT di muka bumi ini. ${ }^{2}$ Hingga ikatan pernikahan ini disebut dengan keluarga. Pernikahan ternyata bukan saja membangun sebuah keluarga, tetapi yang lebih jauh dan itu, pernikahan adalah pilar-pilar bangunan masyarakat. Dengan kata lain suatu masyarakat atau negara akan tersusun dari kumpulan beberapa keluarga, jadi keluarga adalah batu sendi pertama kali terbentuknya masyarakat. ${ }^{3}$

Dalam kehidupan Bermasyarakat dan bangsa ibarat sebuah bangunan, yang memiliki tiang-tiang penyanggah. Bila tiang itu rapuh, bangunan pun ikut rapuh. Bila tiang itu kokoh maka sudah bisa dipastikan bangunan itu kokoh serta mampu berdiri tegak sekalipun diterpa angin kencang. Masyarakat terdiri dari unsur keluarga, dan keluarga terdiri dari unsur individu. Bila anggota keluarga terdiri dari insan-insan shalih, kuat lagi produktif, tentu keluarga akan menjadi shalih dan kokoh.

Bila masing-masing keluarga terdiri dari insan-insan shalih lagi kokoh pasti tercipta lingkungan masyarakat yang sehat, kuat dan mulia. Bila itu terjadi maka bangsa dan negara pun akan aman dan tentram. Islam menaruh perhatian khusus bagi terciptanya keluarga muslim, yang pada gilirannya tercipta suatu masyarakat dan bangsa yang hidup penuh ketentraman, hingga mereka mampu menjadi pemimpi di muka bumi. ${ }^{4}$

Gambaran masyarakat hari ini, terbalik dengan idealitas bahwa keluarga yang seharusnya menjadi pondasi masyarakat yang kokoh dan sehat, tetapi kenyataannya keluarga mengalami krisis, hingga tatanan masyarakat nampak semakin berantakan dengan bukti angka perceraian yang semakin meningkat, kekerasan dalam rumah tangga, budaya selingkuh, perilaku sex pranikah pun meningkat, mulai dari usia SD, SMP hingga merambat ke tingkat yang lain, padahal mayoritas mereka adalah ummat Islam.

\footnotetext{
${ }^{1}$ Abu Bakar Jabir al-Jazairi, Minhajul Muslim, (Beirut: Darul Fikr, 2004), 333. 2008), 207.

2Departemen Agama RI, Al-Qura@n dan Terjemahannya, (Bandung: Syamil Cipta Media,

${ }^{3}$ Arif Budiman, Kuliah Menjelang Pernikahan,Cet. Ke-1(Solo: Studia, 1988),7.

${ }^{4}$ A. Mudjab Mahalli, Menikahlah..., 36.
} 
Prinsip dasar pembinaan keluarga Islami adalah mewujudkan kebutuhan individu dan masyarakat, dalam arti meningkatkan kualitas kemaslahatannya. Kedua faktor itu sama pentingnya untuk diperhatikan, karena keduanya memiliki kaitan yang sangat erat. Para ahli pendidikan sepakat, bahwa keluarga merupakan basis pertama bagi pendidikan individu dan pondasi utama bagi pertumbuhan masyarakat. Persepsi ini muncul dari hasil penelitian yang cermat dan mendalam. ${ }^{5}$

Islam mensyari'atkan kepada manusia tentang keluarga sakinah entah manusia itu berprofesi sebagai guru, nelayan, karyawan bahkan kepada pemain sepak bola pun itu harus diterapkan. Kalau melihat setiap profesi diatas maka yang perlu di garis bawahi dalam hal ini adalah pemain sepak bola, karena inilah yang menjadi pokok pembahasan dalam tulisan ini.

Hasil penelitian awal menggambarkan profesi seorang pemain sepak bola, bahwa profesi ini menuntutnya untuk memberikan jarak antara dirinya dengan keluarga, sehingga keakraban, ketentraman serta keharmonisan dengan istri dan anak perlahan-lahan akan pudar bahkan bisa mengakibatkan perceraian, padahal merupakan suatu keharusan bagi seorang suami untuk selalu dekat dengan istri dan anaknya sehingga dapat tercipta keluarga yang harmonis.

Penelitian ini ditulis untuk mengetahui persepsi pemain persatuan sepak bola indonesia balikpapan (PERSIBA) tentang keharmonisan keluarga.

\section{B. Metode Penelitian}

Penelitian ini menggunakan teknik field research (penelitian lapangan) yaitu mengadakan penelitian langsung ke lapangan untuk mendapatkan dan mengumpulkan data serta mengamati permasalahan dalam penelitian.

Sifat penelitan ini adalah penelitian deskriptif analitik, yaitu mendeskripsikan bahan kajian yang didapat dari berbagai sumber yang berkaitan dengan pokok masalah, kemudian menganalisisnya serta menginterpretasikan terhadap data tersebut.

Metode pengumpulan data dalam penelitian ini, bahwa penulis terjun langsung ke lapangan guna mendapatkan data-data yang diperlukan, yaitu melalui dua cara, Pertama adalah pengamatan, berupa studi yang sengaja dilaksanakan secara sistematis terhadap gejala psikis dan fenomena sosial dengan jalan observasi dan pencatatan. Kedua, wawancara yaitu dengan berkomunikasi secara langsung yang berupa tanya-jawab antara penulis dengan yang diwawancarai (responden) 
secara sistematis berdasarkan permasalahan dan tujuan penelitian.

Teknik pengolahan dan analisis data yang penulis tempuh dalam tulisan ini yaitu melalui beberapa langkah, pertama, klasifikasi data yaitu mengelompokkan data-data sesuai dengan jenisnya masing-masing. Kedua, interpretasi data yaitu menafsirkan data persepsi pemain bola tentang keharmonisan keluarga. Ketiga, editing data yaitu melakukan pengecekan atau seleksi terhadap data yang diperoleh.

Teknik analisis data yaitu dengan mengurai data-data yang ada menjadi satuan kecil kemudian diklasifikasikan. Data yang terkumpul disajikan dalam bentuk uraian deskriptif, kemudian dianalisis secara kualitatif dengan menggunakan ketentuan umum yang berlaku tentang keharmonisan keluarga sesuai dengan landasan teorinya.

\section{Konsep Keharmonisan Dalam Keluarga Islam}

Keluarga harmonis atau keluarga bahagia adalah apabila kedua pasangan tersebut saling menghormati, saling menerima, saling menghargai, saling mempercayai dan saling mencintai. ${ }^{6}$

Keluarga Harmonis yaitu keluarga yang rukun berbahagia, tertib, disiplin, saling menghargai, penuh pemaaf, tolong menolong dalam kebajikan, memiliki etos kerja yang baik, bertetangga dengan saling menghormati, taat mengerjakan ibadah, berbakti kepada yang lebih tua, mencintai ilmu pengetahuan dan memanfaatkan waktu luang dengan hal yang positif dan mampu memenuhi dasar keluarga. ${ }^{7}$

Keluarga harmonis juga merupakan keluarga yang penuh dengan ketenangan, ketentraman, kasih sayang, keturunan dan kelangsungan generasi masyarakat, belas kasih dan pengorbanan, saling melengkapi dan menyempurnakan, serta saling membantu dan bekerja sama. ${ }^{8}$

Keharmonisan atau harmonis mempunyai makna serasi atau selaras. Keharmonisan ialah bentuk hubungan yang dipenuhi oleh cinta dan kasih, karena kedua hal tersebut adalah tali pengikat keharmonisan. Kehidupan keluarga yang penuh cinta kasih tersebut dalam Islam disebut mawaddah wa rahmah. ${ }^{9}$ Ayat 21 1975), 9

${ }^{6}$ Zakiah Dradjat, Ketenangan Dan Kebahagiaan Dalam Keluarga, (Jakarta: Bulan Bintang,

${ }^{7}$ Hasan Basri, Merawat Cinta Kasih, (Yogyakarta: Pustaka Pelajar, 1996), 111.

${ }^{8}$ Ali Qaimi, Menggapai Langit Masa Depan Anak, (Bogor: Cahaya, 2002), 14.

${ }^{9}$ Sa'id bin Abdullah bin Thalib Al-Hamdani, Risalah Nikah, terj. H. Agus Salim, (Jakarta: Pustaka Amani, 2002), Cet. ke-2, 14. 
dari surat ar-Rum mengajarkan bahwa diantara tanda-tanda keagungan dan kekuasaan Allah ialah diciptakan-Nya istri-istri bagi kaum laki-laki dari jenis yang sama, guna menyelenggarakan kehidupan damai dan tentram, serta menimbulkan rasa kasih sayang suami dan istri khususnya, dan ummat manusia umumnya. ${ }^{10}$ Allah berfirman ;

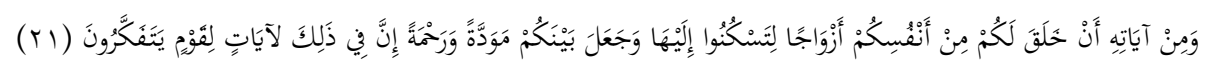

Artinya : Dan diantara tanda-tanda kekuasaan-Nya ialah dia menciptakan untukmu isteri-isteri dar ijenismu sendiri, supaya kamu cenderung dan merasa tenteram kepadanya, dan dijadikan-Nya diantaramu rasa kasih dan sayang. Sesungguhnya pada yang demikian itubenar-benar terdapat tanda-tanda bagi kaum yang berfikir. (QS Ar-Rum: 21)

Pengertian keluarga "harmonis" difahami dari al-Quran surat ar-Rum (30) ayat 21. Pada ayat tersebut menyatakaan bahwa tujuan keluarga harmonis adalah untuk mencapai ketentraman dan kebahagiaan dengan dasar kasih sayang, setiap anggota keluarga serasa dalam suasana aman, tentram,damai, bahagia dan sejahtera namun dinamis menuju kehidupan yang baik di dunia dan di akhirat. Jadi kata "harmonis" yang digunakan untuk mensifati kata "perkawinan" merupakan tata nilai yang seharusnya menjadi kekuatan penggerak dalam membangun tatanan keluarga yang dapat memberikan kenyamanan dunia sekaligus jaminan keselamatan akhirat. Rumah tangga seharusnya menjadi tempat yang tenang bagi setiap anggota keluarga, keluarga menjadi tempat kembali kemanapun anggotanya pergi. Mereka merasa nyaman di dalamnya, dan penuh percaya diri ketika berinteraksi dengan keluarga yang lainnya dalam masyarakat. ${ }^{11}$

Dalam buku "al-Quran dan tafsirnya" dijelaskan bahwa, masing-masing mereka (suami-istri) merasa tentram hatinya dengan adanya pihak yang lain itu. Semua ini merupakan modal paling berharga dalam membina rumah tangga (keluarga) bahagia. Kemudian dengan adanya rumah tangga yang bahagia jiwa dan pikiran menjadi tentram, tubuh dan hati mereka menjadi tenang serta kehidupan menjadi mantap, kegairahan hidup akan timbul, dan ketentraman bagi laki-laki dan wanita secara menyeluruh akan tercapai. ${ }^{12}$

Di dalam al qur`an Allah swt. Menggambarkan apa yang seharusnya dilakukan oleh seorang suami terhadap keluarganya agar tercipta hubungan yang

${ }^{10}$ Ahmad Azhar Basyir, Hukum pernikahan Islam,Cet, ke-9, (Yogyakarta: UUI Press, 1999), 2.

11Paryadi, Keluarga Militer, 31.

12Bustami A. Gani, et. al., Al-Qura@n dan Tafsirnya,jilid VII, (Yogyakarta: PT. Dana Bhakti Wakaf, Universitas Islam Indonesia, 1991), 522. 
harmonis, yaitu disaat Nabi Ibrahim berdo`a untuk keluarganya, dalam surat ibrahim Allah berfirman :

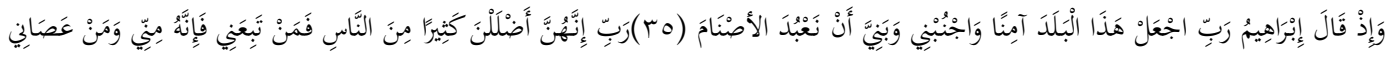

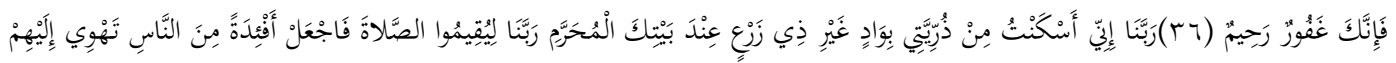

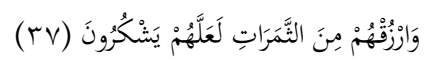

Artinya : Dan (ingatlah), ketika Ibrahim berkata: "YaTuhanku, jadikanlah negeri Ini (Mekah), negeri yang aman, dan jauhkanlah Aku beserta anak cucuku daripada menyembah berhala-berhala.

YaTuhanku, Sesungguhnya berhala-berhala ituTelah menyesatkan kebanyakan dari pada manusia, Maka barangsiapa yang mengikutiku, Maka Sesungguhnya orang itu termasuk golongan ku, dan barangsiapa yang mendurhakai aku, Maka Sesungguhnya Engkau, Maha Pengampun lagi Maha Penyayang.

YaTuhan kami, Sesungguhnya Aku Telah menempatkan sebahagian keturunanku di lembah yang tidak mempunyai tanam-tanaman di dekat rumah Engkau (Baitullah) yang dihormati, YaTuhan kami (yang demikianitu) agar mereka mendirikan shalat, Maka jadikanlah hati sebagian manusia cenderung kepada mereka dan beri rezkilah mereka dar ibuah-buahan, Mudah-mudahan mereka bersyukur. (QS Ibrahim: 35-37)

Nabi Ibrahim berdo'a agar ia dan keturunannya dihindarkan Allah Swt dari perbuatan menyembah berhala, karena perbuatan itu menyesatkan manusia dari jalan yang benar ke jalan yang salah. Selanjutnya Ibrahim menerangkan barangsiapa di antara anak cucunya yang mengikutinya yaitu beriman kepada Allah dengan sepenuh hati itulah orang yang mengikuti agamanya. ${ }^{13}$

Ayat ini menerangkan saat nabi Ibrahim as akan kembali ke Palestina menemui istrinya Sarah, meninggalkan istrinya Hajar dan puteranya Ismail yang masih kecil di Makkah, di tengah-tengah padang pasir yang tandus, tanpa ditemani seorang manusia pun, tanpa bekal untuk keluarganya yang di tinggalkan. ${ }^{14}$

Selanjutnya diterangkan bahwa Ibrahim as, agar Allah memelihara keturunannya yang ada di Makkah, menjadikan mereka sebagai orang yang taat mengerjakan shalat, menghamba dan menundukkan dirinya kepada Allah agar memelihara keturunannya itu, menjadikan hati manusia cenderung kepadanya (ka`bah), cinta kasih itu diberi rizki, didatangkan bahan makanan, buah-buahan, ke

13Ibid, 194.

14Ibid, 195. 
Negeri yang tandus itu. ${ }^{15}$

Inilah gambaran kongkrit dalam membina rumah tangga untuk mengajarkan nilai-nilai tauhid kepada keluarga sehingga hal ini yang nantinya menjadi modal untuk menjaga keharmonisan dalam rumah tangga.

Ada beberapa kriteria yang harus dimiliki dan terapkan dalam rumah tangga sehingga keharmonisannya dapat terjaga ;

a. Memiliki rasa cinta dan kasih sayang

Jika suatu keluarga atau rumah tangga tidak memiliki rasa cinta dan kasih sayang, maka bisa dipastikan rumah tangga itu memiliki kelemahan, karena cinta dan kasih sayang adalah power untuk menjalankan kehidupan rumah tangga yang harmonis.

b. Adaptasi

Adaptasi merupakan penyesuaian dari masing-masing suami istri baik dari segi perbedaan ide, tujuan, kesukaan, kemauan dan semua hal yang melatarbelakangi masalah. Hal itu didasarkan pada satu tujuan yaitu keharmonisan keluarga. ${ }^{16}$

c. Nafkah lahir dan batin

Dengan pemenuhan nafkah lahir batin, maka harapan keluarga dan anak dapat terealisasi sehingga tercipta kesinambungan dalam keluarga. ${ }^{17}$

d. Sosial dan ekonomi

Kondisi sosial dan ekonomi yang cukup memadai untuk memenuhi hidup berkeluarga. Hal ini dapat berupa semangat dan etos kerja yang baik dalam memenuhi nafkah, kreatifitas dan semangat untuk mengusahakannya, sehingga keluarga akan terpenuhi kebutuhannya. ${ }^{18}$

e. Menciptakan kehidupan agama

Menciptakan kehidupan agama atau spiritualitas dalam keluarga. Karena dalam agama terdapat nilai-nilai moral atau etika kehidupan. Landasan utama agama dalam kehidupan terutama rumah tangga adalah kasih sayang. Penelitian mengatakan keluarga yang tidak religius, komitmen agamanya rendah, atau yang tidak mempunyai komitmen sama sekali beresiko akan tidak bahagia, dan berakhir dengan broken home. ${ }^{19}$

15 Ibid, 189.

16Dlori, Muhammad M, Dicintai Suami (Istri) Sampai Mati, (Jogjakarta: Katahati, 2005), 30-32.

${ }^{17}$ Ibid., 16-23.

18Basri, Op. Cit., 32-37

19Ibid., 16-23. 
Dalam terapannya keluarga memiliki fungsi yang harus dijalankan agar keseimbangan didalam rumah tangga tersebut bisa sesuai dan terarah dalam mencapai tujuan dari keluarga yang bahagia, Dalam kamus Ilmiah Populer Fungsi diartikan dengan beberapa hal: jabatan, kedudukan, peranan, guna, kegunaan atau manfaat. ${ }^{20}$ Jadi fungsi keluarga adalah satu pekerjaan atau tugas yang harus dilaksanakan di dalam atau oleh keluarga tersebut. Menurut Muhammad Taufik asSamuluthi pekerjaan-pekerjaan yang harus dilaksanakan oleh keluarga dapat di golongkan ke dalam beberapa fungsi:

a. Fungsi biologis, keluarga adalah tempat penyaluran hasrat, keluarga diwajibkan untuk berusaha agar setiap anggotanya mendapatkan perhatian, cinta, kasih sayang dan ketenangan.

b. Fungsi ekonomi, keluarga berusaha menyelenggarakan kebutuhan anggota keluarga yang pokok baik pangan, sandang dan papan.

c. Fungsi keagamaaan, bahwa keluarga bertanggung jawab dalam menanamkan aqidah yang benar dan nilai-nilai Ilahiyyah kedalam jiwa anak-anaknya. Memberikan teladan anggota keluarganya dalam pelaksanaan nilai-nilai serta ajaran agama secara lengkap dan sempurnah, baik ketika sendiri, bersama keluarga atau berada di masyarakat luas.

d. Fungsi sosial, keluarga harus mempersiapkan anak-anaknya untuk di tengahtengah masyarakat dengan mengenalkan dan memahamkan aturan-aturan, nilai-nilai dan sikap-sikap yang dianut oleh masyarakat. ${ }^{21}$

Agar fungsi keagamaan berjalan dengan benar maka keluarga diharapkan mengutamakan lingkungan yang shalihah dan menghindari lingkungan yang merusak, pertimbangan awal yang semestinya diagendakan adalah keshalihan bi'ah (lingkungan). ${ }^{22}$

Keluarga merupakan bi'ah fitriyah-syar'iyah manusia, perlu sekali ummat Islam menyadari bahwa keluarga merupakan salah satu tahapan perjuangan dalam menegakkan Islam. Islam sebagai sistem sosial yang lengkap, tidak dapat tegak hanya oleh perjuangan individu-individu sendirian. Islam harus tegak dalam satu sistem sosial karena manusia memang makhluk sosial. Dan satu tatanan sosial yang

20 Pius A. Partono, M. Dahalan Al-Barry, Kamus Ilmiah Populer..., 190.

21Paryadi, "Keluarga Militer..., "yang mengutip dari karangan Nabi Muhammad Taufik asSamaluthi, Pengaruh Agama Terhadap Struktur Keluarga, Terj. Ansor Umar Sitanggal, (Surabaya: P.T. Bina Ilmu, 1987), 89.

${ }^{22}$ Cahyadi Takariawan, Perni-Pernik Rumah Tangga Islami,Cet, ke-5, (Surakarta: Era Inter Media, 2007), 248. 
kokoh hanya akan terbentuk dari tatanan-tatanan sosial lebih kecil yang juga kokoh.

Tatanan kecil itulah unit terkecil dari masyarakat, unit itu adalah keluarga. Individu hanyalah elemen, bukan unit, karena sebuah unit harus terdiri dari beberapa elemen yang mempunyai aneka fungsi dan kedudukan. Seorang ulama mujaddid abad 20 menyebutkan urutan-urutan perjuangan sebagai berikut: (1) pembinaan pribadi muslim (2) pembinaan keluarga muslim (3) pembinaan masyarakat Islam dan seterusnya sampai kepada tegaknya Islam diseluruh penjuru jagad raya. ${ }^{23}$

Keluarga berperan dalam pembinaan masyarakat, diperlukan sebuah upaya ishlahul mujtama' di sekitarnya menuju pemahaman yang benar tentang nilai-nilai Islam yang shahih untuk kemudian berusaha bersama-sama membina diri dan keluarga sesuai dengan arahan Islam, keluarga Islami harus memberikan kontribusi yang cukup bagi kebaikan masyarakat sekitarnya. ${ }^{24}$

\section{Keharmonisan Keluarga Pemain Sepak Bola (Persiba) dan Analisis}

Penelitian ini difokuskan dengan mengambil contoh kasus keluarga pemain sepakbola khususnya pemain persiba balikpapan, yang meninggalkan keluarganya di kampung halaman dikarenakan tuntutan profesi untuk mencari nafkah. dalam penelitian ini ada dua kasus pemain sepak bola yang diteliti;

1. Kasus pertama.

Fathul Rahman (bek), umur 34 tahun, menikah tahun tahun 2015, dari pernikahan itu Fathul Rahman dikaruniai anak satu. Fathul Rahman menggemari sepak bola sejak dari SD dan memfokuskan dirinya menjadi pemain sepak bola sejak SMA, sedangkan Fathul Rahman masuk ke club persiba mulai tahun 2018 setelah sebelumnya berada di PSM dan barito. Keadaan ini membuat Fathul Rahman harus berpisah dari keluarganya terutama istri dengan anaknya yang masih kecil, apalagi keluarganya berada dimakassar sementara dia berada di Balikpapan. Adapun keadaan keluarganya di rumah merasa sedih karena mau tidak mau harus berpisah darinya, apalagi jadwal pertandingan persiba yang padat mulai dari Piala Presiden, dan Piala Gubernur. Terkadang dia bisa pulang ke makassar hanya sebulan sekali

${ }^{23}$ Muhammad Ihsan Tanjung, "Kajian Islam Berkala II-2001", kerjasama : BDI Pertamina, BDI Totalfinalelf E\&P Indonesia, BDI Unocal, (Balikpapan: 2001), 5. t.d

${ }^{24}$ Ibid, 44. 
atau bahkan sampai tiga atau empat bulan baru bisa pulang. Akan tetapi yang dilakukan oleh Fathul Rahman agar keluarganya tetap harmonis, bahwa dia tidak lupa selalu berkomunikasi meskipun hanya lewat telepon. yang kedua dia dan istrinya mempunyai keterbukaan. Karena biasanya anggapan orang terhadap pemain sepak bola itu macam-macam, ada yang negatif ada juga yang positif, katanya. Istrinya juga merasa bahagia dengan keterbukaan suaminya kepadanya, misalnya istrinya menginginkan untuk dibelikan hadiah olehnya, maka ia langsung melakukannya, begitu juga setiap ada masalah atau percekcokan yang terjadi di antara mereka, maka mereka langsung menyelesaikannya dengan tanpa rasa kaku. Adapun anggapan orang bahwa pemain bola itu biasanya selalu menyimpang dari keluarga atau selingkuh, itu bisa teratasi dengan keterbukaan dengan istri, jadi entah istrinya mau berpikir ke situ atau tidak, yang penting dia sudah terbuka, begitu juga sebaliknya, kata Fathul Rahman. Sehingga keadaan keharmonisan rumah tangga saat FR berada di rumah maupun sudah di luar, itu hampir tidak ada bedanya, karena hampir setiap hari berkomunikasi meskipun hanya lewat telpon, sebelum menikah juga Fathul Rahman menceritakan kepada istrinya tentang keadaan seorang pemain sepak bola itu tidak selamanya di rumah sehingga istrinya sudah memahami keadaanya. Meskipun Fathul Rahman berada di Balikpapan dan jauh dari istrinya, Fathul Rahaman tidak lagi berfikir untuk untuk mencari wanita lain atau hal-hal yang menyimpang dari keluarga, karena semua itu katanya, hanya membuang-buang waktu. Maka Yang paling berperan dalam memunculkan keharmonisan rumah tangganya adalah dia sendiri, biasanya dia mengajak istrinya bercanda, begitu pun istrinya menimpali candaan itu. Keharmonisan itu juga bukan hanya terjadi di dalam rumah bahkan lewat telefon atau sering jalan-jalan bersama. Adapun gaji dari profesi dia sebagai pemain sepak bola perbulan maka Fathul Rahman membagi-bagikannya kepada orang tuanya, istri dan anaknya.

\section{Kasus kedua.}

Barep Wahyudi (kiper), asal Solo menikah tahun 2016 dan dikaruniai anak satu, Barep Wahyudi menggemari bola sejak kecil dan masuknya ke klub persiba pada bulan desember 2017. Situasi inilah yang membuatnya meninggalkan rumah dan keluarganya di Solo menuju Balikpapan, akan tetapi Barep Wahyudi memasang target bahwa sebulan harus sekali pulang. Sekalipun terkadang tiga sampai empat bulan di Balikpapan baru bisa pulang di karenakan jadwal persiba yang sangat padat, mulai dari Piala Presiden hingga Piala Gubernur, sehingga waktu latihan dan waktu bertanding itulah yang membuatnya tidak bisa pulang ke rumah. Namun cara 
yang dilakukannya untuk selalu akur dan harmonis dalam keluarga adalah bahwa dia tidak memutuskan komunikasi bahkan hampir setiap hari video call dengan keluarganya, mulai dari sebelum tidur, setelah selesai latihan. apalagi anaknya yang pernah sakit dan dirawat di rumah sakit dan dia tidak sempat menjenguknya disaat anaknya dioprasi sehingga orang tua dari Barep Wahyudilah yang membantu merawat anaknya. Untuk menjaga keharmonisan, Barep Wahyudi selalu terbuka dengan istrinya, begitupun istrinya sehingga tidak ada kekakuan di dalam rumah tangga mereka. Batas maksimal dia pulang ke rumah itu hanya tiga hari sehingga hanya sedikit waktu mereka untuk bersama. Hanya karena sifat keterbukaan itulah yang membuat keluarga Barep Wahyudi selalu harmonis. terkadang sering juga terjadi konflik dan percekcokan di antara mereka, misalnya ada sesuatu yang membuat istrinya menjadi marah, maka Barep Wahyudi menanggapinya dengan senyuman dan candaan, akhirnya mereka akur kembali. maka yang sering memunculkan keharmonisan dalam rumah tangga adalah Barep sendiri, contohnya Barep Wahyudi selalu mengajak keluarganya ke pantai dan itu hampir setiap dia pulang dari pekerjaannya kebiasaan itulah yang sering dia lakukan. Pendapatan atau gajinya perbulan itu Sembilan puluh persen untuk keluarga, karena menurutnya yang paling utama itu adalah keluarganya dan setelah itu baru dirinya. Keharmonisan itu juga muncul bukan hanya di dalam rumah, akan tetapi di luar rumah pun demikian. Orang tua dari Barep Wahyudi juga mendukung profesinya sebagai pemain sepak bola, akan tetapi harus ada investasi untuk masa depan karena tidak selamanya dia akan menjadi pemain sepak bola bola.

Dari uraian kasus yang ada diatas maka dapat diketahui bahwa kehidupan keharmonisan pemain sepak bola Indonesia Balikpapan(PERSIBA), sebagaimana kita saksikan di masyarakat banyak di antara mereka para suami jarang pulang karena mencari nafkah. Bahwa suami bukan hanya di tuntut untuk mencari nafkah dan mencukupi kehidupan dalam rumah tangga tetapi suami juga dituntut untuk menyelesaikan tugasnya sebagai pemimpin dalam rumah tangganya, yakni memimpin istrinya dalam hal-hal yang menyangkut tentang hukum-hukum agama yang harus diketahuinya sekaligus mendidik anak-anak, mulai dari memperhatikan tentang pendidikan anak di sekolah sampai pada memberikan nafkah secara rutin untuk mencukupi kehidupan rumah tangganya dan sebagainya. Sebagaimana dalam firman Allah dalam QS. At-Tahrim ayat: 6

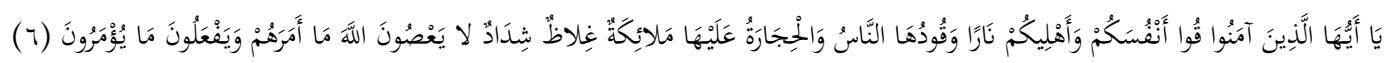


Artinya : hai orang-orang yang beriman,

peliharalahdirimudankeluargamudariapi neraka yang bahanbakarnyaadalah manusia danbatu; penjaganya malaikat-malaikat yang kasar, keras, dantidakmendurhakai Allah terhadapapa yang diperintahkan-Nya kepada mereka danselalu mengerjakan apa yang diperintahkan. (QS At-Tahrim:6)

Sehingga dalam hal ini seorang suami di perintahkan untuk menasehati keluarganya, memerintahkan mereka melakukan kebaikan dan mencegah mereka dari kemungkaran. Di antara kewajiban seorang suami adalah mendidik istri mereka, tentang hukum-hukum agama yang harus diketahuinya. Hendaklah seorang suami membimbing dan mengajarinya hal-hal yang berhubungan dengan masalah fiqhiyah jika seandainya dia tidak mengetahuinya. Sebagaimana Hadits Riwayat Bukhari yang artinya :

Nasihatilah para wanita (istri) itu dengan baik, sesungguhnya wanita itu tercipta dari tulang rusuk yang bengkok. Bila engkau biarkan akan tetap bengkok, tetapi jika engkau luruskan, akan patah maka nasihatilah wanita itu dengan baik.(HR. Bukhari)

Semua yang diperbuat oleh istri menjadi tanggung jawab suaminya, baik itu masalah ibadah, muamalah maupun akhlak istrinya. Sehingga jika hal ini diperhatikan oleh suaminya maka seorang istri juga mendapat perhatian sehingga dia berusaha melakukan hal tersebut dengan baik.

Tidak memberikan nafkah kepada keluarga termasuk perbuatan yang dilarang oleh Allah dan sudah menjadi pengetahuan umum bahwa kewajiban suami adalah memberikan nafkah kepada istrinya, bagi istri yang bekerja pun tetap saja memberikan sebagian penghasilannya kepada istri sebagai bentuk kewajiban kepala rumah tangga. Dalam kehidupan rumah tangga suamilah yang bertanggung jawab menafkahi keluarganya dan suamilah yang menjadi kepala rumah tangga. Sebagaimana disebutkan dalam UU Perkawinan No 1 tahun 1974 dalam pasal 34 tentang nafkah diatur sebagai berikut ;

a. Suami wajib melindungi istrinya dan memberi segala keperluan hidup berumah tangga sesuai dengan kemampuannya.

b. Istri wajib mengatur rumah tangga dengan sebaik-baiknya. ${ }^{25}$

Adapun Kompilasi Hukum Islam menjelaskam bahwa nafkah merupakan kewajiban suami. Hal ini ditegaskan dalam pasal 80 ayat 4, yaitu sesuai dengan 
penghasilannya suami menanggung.

1) Nafkah dan tempat tinggal bagi istri

2) Biaya rumah tangga, biaya perawatan dan biaya pengobatan bagi istri dan anak.

3) Biaya pendidikan bagi anak. ${ }^{26}$

Pemberian nafkah meliputi kebutuhan makan dan minum, pakaian, tempat tinggal, dan kebutuhan wajib/pokok lainnya yang biasa diperlukan bagi istri dan anak-anaknya. Sabda Rasulullah saw:

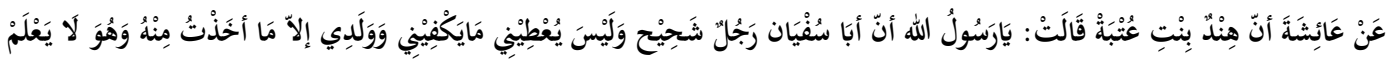

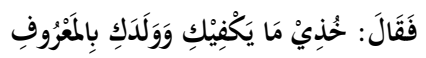

Artinya : 'Aiysah meriwayatkan bahwa Hindun binti Utbah berkata, "wahai Rasulullah, sungguh Abu Sufyan (suami Hindun) adalah seorang laki-laki yang sangat pelit. Ia tidak pernah memberi nafkah yang dapat mencukupi kebutuhanku dan anakanakku, kecuali jika aku mengambil harta suamiku tanpa sepengetahuannya." Maka Rasululah bersabda, ambillahdari harta untuk mencukupi kebutuhanmu dan anakanakmu dengan cara yang baik."27

Rezeki yang diberikan oleh Allah harus diinfakkan kepada orang yang membutuhkannya, khususnya kepada keluarganya yang tidak boleh diabaikan meskipun istrinya punya kelebihan harta. Apalagi suaminya berpenghasilan yang lebih dibandingkan orang pada umumnya, yang seharusnya diberikan sesuai apa yang dibutuhkan keluarganya

Dalam hal seorang suami meninggalkan istri juga telah ada tuntunan dan contoh dalam riwayat sahabat Rasulullah saw. Sebagaimana yang dikisahkan oleh Umar Radhhiyallahu anhu dia bertanya, kepada anak perempuannya "Hafsah berapa lama seorang istri dapat bersabar menunggu, suaminya?," Hafsah menjawab, "empat atau enam bulan," lalu Umar Radhiyallahu anhu berkata: "saya tidak akan menahan seorang tentara dari bilangan itu." Ini adalah kisah seorang wanita yang ditinggal pergi, suaminya berjuang di jalan Allah dan suaminya terlambat pulang, lalu dia merasakan kerinduan yang begitu mendalam terhadap suaminya kalau saja tidak ada rasa takut kepada Allah niscaya dia akan melakukan yang dimurkai Allah (berzina). Suami yang bekerja dan meninggalkan keluarganya dalam waktu yang lama, maka sepatutnya tidak menimbulkan permasalahan diantara keduanya,

26 Abdurrahman, Kompilasi Hukum Islam,Cet. ke VI, (Jakarta: Akademika Pressindo, 2004), 133
${ }_{7}$ Syaikh Muhammad Asy-Syarif, Empat Puluh Hadits Wanita (Solo: Aqwan, 2009), 309 
namun harus saling memahami di antara keduanya, karena sebaik-baik orang yang beriman adalah orang yang paling baik akhlaknya, dan orang yang paling baik diantara kamu adalah orang yang sangat baik kepada istrinya. ${ }^{28}$ Melihat dari tugas seorang suami yang harus bepergian jauh dan tidak pulang dalam waktu yang lama untuk mencari nafkah dan merangkap sebagai pimpinan kepala rumah tangga. Maka dalam hal ini adalah merupakan sesuatu hal yang tidak melanggar syariat, dikarenakan suami memiliki kewajiban dan tanggung jawab untuk menafkahi istrinya, akan tetapi sang suami harus memperhatikan kebutuhan nafkah lahir dan batin sang istri sehingga keharmonisan rumah tangga tetap terjaga.

Demikian konsep yang harus dilaksanakan oleh setiap suami agar dapat menunaikan kewajibannya sebagai kepala rumah tangga sekaligus pemimpin istri dan anak-anaknya begitu juga dengan kewajibannya untuk selalu mempertahankan keharmonisan rumah tangganya.

\section{E. Kesimpulan}

Berdasarkan uraian yang telah dipaparkan diatas, dapat disimpulkan bahwa keharmonisan keluarga pemain sepak bola persiba balikpapan pada kasus yang telah diteliti adalah baik, Profesi sebagai pemain sepak bola yang sering meninggalkan keluarga dalam waktu yang lama ternyata tidak menyebabkan hubungan keluarga menjadi tidak harmonis, akan tetapi malah justru keluarga tersebut semakin harmonis di karenakan baik suami maupun istri sama-sama memahami tugas dan fungsi masing-masing dalam keluarga, ditambah lagi dengan intensnya dalam berkomunikasi meretas permasalahan-permasalahan yang kadang muncul ke permukaan semuanya dapat terselesaikan dengan baik karena adanya kejujuran dan keterbukaan antara suami istri meskipun hanya melalui telepon seluler.

Dalam tinjauan hukum Islam, seorang suami yang meninggalkan keluarganya untuk mencari nafkah meskipun dalam rentang waktu yang lama, namun hal tersebut tidak bertentangan dengan syari’at, karena profesi yang dia geluti mengharuskan dirinya untuk meninggalkan keluarga, serta tidak menghambat terwujudnya keharmonisan rumah tangga atas dasar saling pengertian antara suami istri.

28 Miftah Farid, Rumahku Surga (Jakarta: Gema Insani 2005), 133 


\section{Daftar Pustaka}

Amir. Nuruddin, dan Azhari Akmal Taringan. Hukum Perdata Islam Indonesia: Studi Kritis Perkembangan Hukum Islam Dari Fikih, UU/1974 Sampai KHI. Jakarta: Prenadamedia Group, 2016), Cet. ke-6.

an-Nawawi, Muhyiddin. Shohih Muslim (Beirut: Darul Ma'rifah, 1998), No. 3434.

Hawari, Dadang.al-Qur'an Ilmu Kedokteran Jiwa dan Kesehatan. Jakarta: Bhakti Prima Yasa, 1996.

Hukum Online, “Undang-Undang Republik Indonesia Nomor 35 Tahun 2014 Tentang Perubahan Atas Undang-Undang Nomor 23 Tahun 2002 Tentang Perlindungan Anak," diakses pada 07 Januari 2019. www.hukumonline.com. Adobe PDF eBook.

Husain, Muhammad. Fiqh Perempuan. Yogyakarta: Liks, 2001. Google Book.

Majelis Permusyawaratan Rakyat Republik Indonesia, Undang-Undang Dasar Negara Republik Indonesia Tahun 1945, 65.

Muhammad, Abdullah bin. Luhbatut Tafsir Min Ibni Katsir. trans M. Abdul Ghoffar. Jakarta: Imam Syafi'i, 2016, Cet. 9.

Muslikhati, Siti. "Feminisme Dan Pemberdayaan Perempuan Dalam Timbangan Islam, 116.

Muthiah, Aulia. Hukum Islam Dinamika Seputar Hukum Keluarga,63.

Quthb, Sayyid. Fi Zhilalil Qur'an, trans. As'ad Yasin et.al. 347.

Radar Cirebon. "MUI Sebut Putusan MK Menimbulkan Polemik." diakses pada 20 Desember 2018.http://www.radarcirebon.com. Adobe PDF eBook.

Ridha, Muhammad Rasyid,Tafsir al-Manar Juz I. Mesir: al-Manar, 2000.

Syafruddin, Amir. Hukum Perkawinan Islam di Indonesia. Jakarta: Prenamedia Group, 2014, Cet. Ke-5.

Undang-Undang Republik Indonesia No. 48 Tahun 2009,“Kekuasaan Kehakiman,” di akses 03 Februari 2019. http://UU no 48 th 2009.pdf. Adobe PDF eBook.

Uwaidah, Kamil Muhammad. al-Jami' fii Fiqhi an-Nisa', trans. M. Abdul Ghoffar Jakarta: Pustaka al-Kautsar, 2012. 